\title{
CREDIT MANAGEMENT, CREDIT POLICY AND FINANCIAL PERFORMANCE OF COMMERCIAL BANKS IN UGANDA
}

\author{
Patrick W. Mafumbo \\ Quality Assurance Officer, Victoria University Uganda \\ Lecturer, Faculty of Business \& Management, Victoria University Uganda
}

\begin{abstract}
This study was carried out with the purpose of analyzing the effects of credit management on the financial performance of commercial banks in Uganda. Specifically, the study sought to establish whether there is a relationship between credit policy and performance, Capital Adequacy and performance and credit risk control and performance. In achieving the objectives assigned by the study, a causal research design was undertaken and that was facilitated by the use of secondary data which was obtained from published audited financial statements of commercial banks and the BOU annual supervision reports. The study used universal sampling techniques, where all banks licensed and operational in Uganda were selected, multiple regression was used. The findings indicated a significant relationship $(r=$ $0.639)$ between credit management and the financial performance of commercial banks in Uganda. The coefficient of determination $R^{2}$ was 0;408 meaning that credit management indicators explain up to $40.8 \%$ of variations in the financial performance of commercial banks in Uganda. The results from the coefficients summary in the regression model indicate that the significance of coefficients of credit policy (LR), capital adequacy (CAR) and Credit Risk Control (NPL/TL) are $0.031,-0.555$ and -1.005 respectively. It was therefore found that both the CAR and the NPL/TL are significant though have an impact at different significance i.e. capital adequacy and Credit Risk control have a greater impact compared to Credit policy (LR) on the financial performance of commercial banks in Uganda. It was established that there is no significant relationship between credit policy and performance of banks in Uganda, however, a significant relationship between the credit risk control, capital adequacy and the performance of commercial banks was established. It was recommended that should use a moderate credit policy as a stringent credit will undermine the financial performance. Moreover, commercial banks should seek to adequately control their credit risk by keeping lower their ratio of nonperforming loans which is the major determinant of commercial banks' financial performance as shown in the study. The bank of Uganda should encourage banks in Uganda to use credit metrics model in controlling its risks
\end{abstract}

KEYWORDS: credit management, credit policy, financial performance, commercial banks, Uganda

\section{INTRODUCTION}

Banks are financial institutions which play a role of financial intermediation between people in excess of funds and those in need of finances. This role is essentially performed by accepting different types of deposits, e.g. money at call, fixed deposits, saving, etc. for further lending to the numerous customers by way of loan and advances (Jackson, 2011). Banking begins with the first prototype banks of merchants of the ancient world, which made grain loans to farmers and traders who 
carried goods between cities. This began around $2000 \mathrm{BC}$ in Assyria and Babylonia (Rabbi, 2010). In the modern sense of the word, it can be traced to medieval and early renaissance Italy, to the rich cities in the north such as Florence, Venice and Genoa. A chamber of loans was created for the express purpose of looking after loans granting, origination and recovery (Hildreth, 2001). According to Furletti (2002), in the past reputation was usually used by lots of local banks in the credit granting process to local borrowers with incomplete and often unverifiable information.

The developments in telecommunications and computing came with major changes in banks' operations letting banks dramatically increase in size and geographic spread; regulation and consolidation have led to highly automated credit management systems and financial performance's assessment that compile far more detailed and complete information, complying with a range of policies and regulations designed to protect the interest of depositors (Furletti, 2002).

Financial performance is crucial for a commercial bank to attain its going concern issue, banks being at the center of financial sector can disrupt the entire economy if their inherent challenge, credit management is not handled properly. The immediate cause of the last financial crisis of 2007-2008 is coined by many as the bankruptcy of lehmans and brothers, a global bank that took advantge of securitization to start granting credits to low income and underscored borrowers (Mike, 2016).

Banking in East Africa started at the beginning of the $20^{\text {th }}$ century. The setting of the british's representative office through the Imperial British East Africa (IBEA) company attracted the National Bank of India, which sought to be its banking agent (Nelson et al., 2009). However, the locally-owned banks came into play just after the independence periods (mid 60s). Cooperative Bank was the first one to be established in Kenya (Jackson, 2011). In Uganda the banking industry at the time was dominated by government owned institutions (Nsambu, 2014). The bank of Belgian Congo in Rwanda issued its first convertible bank notes of 20, 10 and 1000 francs, the Banque d'Emission du Rwanda et du Burundi (B.E.R.B.) was subsenquently established by a decree in 1960. The East African Development Bank (EADB) established in 1967, was jointly owned by Uganda, Kenya and Tanzania. It was at time essentially concerned with development finance (Wikipedia, 2017).

Government-owned institutions dominated most banking in Uganda before Uganda's independence in 1962. In 1966, the Bank of Uganda (BoU), which controlled the issue of currency and managed foreign exchange reserves, became the central bank and national banking regulator. As of 2017, the banking industry in Uganda remains resilient to shocks with adequate capital and liquidity buffers. (Bank of Uganda, 2017). This research was guided by the credit metrics model which is the first readily available portfolio model for evaluating credit risk (Morgan et al., 2017). The Credit Metrics approach enables a company to consolidate credit risk across its entire organization, and provides a statement of value-at-risk (VaR) due to credit caused by upgrades, downgrades, and defaults. (JP Morgan \& Bank of America, Bank of Montreal, Swiss Credit Union, 2017). 
International Journal of Business and Management Review

Vol.8, No.5, pp.68-99, August 2020

Published by ECRTD-UK

Print ISSN: 2052-6393(Print), Online ISSN: 2052-6407(Online)

The 5 Cs model of credit: The $5 \mathrm{Cs}$ theory is a set of concepts that help commercial banks to increase credit portfolio performance, as they get to know their customers better. These 5Cs include character, capacity, collateral, capital and condition.

The Basel II theory another model developed by a group worldwide highly reputable in financial and banking industry, it's essentially a framework that consists of standards for measuring, managing and supervising capital requirements of a bank. (Bank of International Settlement, 2008).

A set of concepts have been used to capture our independent and dependent variables: credit policy: it encompasses the settings under which a commercial bank extends credit to its customers and defines organizational desired outcomes of credit activities by governing the actions and procedures to be undertaken to attain that goal (Business Dictionary, 2017). In this study, credit policy was measured by the lending ratio which is the ratio of net loans to total deposits; Credit risk control: a set of ways devised to avoid or lessen the risk of default of an obligator to fully meet their commitments in a timely manner. The management of a credit risk covers: Origination, Loan or debt management, collection and recovery (PWC, 2017). Credit risk control was measured using the ratio of nonperforming loans to total loans.

A capital Adequacy (CAR) is a measure of a bank's capital. It is expressed as a percentage of a bank's risk weighted credit exposures. Correspondingly known as capital-to-risk weighted assets ratio (CRAR), is used to protect depositors and promote the stability and efficiency of financial systems around the world. CAR is a part of international credit standards as enacted by the Basel Committee on Banking Supervision (BCBS) providing a forum for regular cooperation on banking supervisory matters. Its objective is to enhance understanding of key supervisory issues and improve the quality of banking supervision worldwide (Bank for International Settlements, 2001). The capital adequacy ratio (CAR) is disclosed by banks in Uganda following the Central Bank's guideline suggesting that both onbalance sheet and off-balance sheet risk exposure should be taken into account when assessing the capital management (Total capital/Risk weighted asset).

According to the Bank of Uganda (2017), the key financial soundness indicators show that commercial banks' performance declined in 2016. The ratio of Tier 1 capital to risk weighted assets (RWA) held by commercial banks fell from 18.6 percent at the end of 2015 to 17.3 percent at the end of 2016, although the latter was still well above the regulatory minimum of 8 percent. The strong capital and liquidity buffers held by banks provide the banking system with a high degree of resilience to shocks such as losses on their loan portfolios. Annual net after tax profits increased by 11.5 percent to USh. 541.2 billion between December 2014 and December 2015 . However, asset quality deteriorated with the level of non-performing loans (NPLs) to total gross loans rising from 5.3 percent to 10.5 percent between December 2015 and December 2016. This led to a slowdown of private sector credit growth and a drop in bank profitability.

The threatening economic environment predicted in August 2015 by top banking executives appears to have claimed its first victim, the recent case is the Case of Crane Bank which according to Kaboyo (2016), had a higher appetite to lend and 
finance the real estate sector to an extent higher than structured by the Bank of Uganda. Political connections and inside lending may have lessened the bank effectiveness in credit granting by delivering loans regardless to the established credit policy, credit risk control and collection policy. The aforementioned issues were among the factors that led to the financial distress of the National Bank of Commerce Uganda (NBCU) which was taken over by Crane Bank in 2012. The latter happened to face the same difficulties due to the same causes. Crane Bank's depositors were transferred to DFCU Bank by the BOU litigator last year (Wikipedia, 2017).

Bank of Uganda in its quest to a sound banking sector instituted throughout the year 2015 several regulatory reforms. The Financial Institutions Act 2004 was amended in January 2016. This has paved way for the implementation of Agent Banking, Islamic Banking, bancassurance, the revision of capital requirements and the reform of the deposit protection fund (DPF). Bank of Uganda put in place initiatives to implement these reforms in 2016. The implementation of the Capital Conservation Buffer was expedited in order to further strengthen bank soundness emphasizing on the sustainability by increasing performance.

\section{Statement of the Problem}

Nduwayo A. (2015) explains the role of commercial banks as: creation of money, payment mechanism, pooling of saving, extension of credits, financing of foreign trade, trust service, safekeeping of variables and brokerage services. Back in 1988 with the credit crisis, BCCI went to a massive bankruptcy due according to The Guardian (2015) to an inadequate credit policy. The financial crisis of 2007-2008 caused many bank failures, including one of the world's largest banks, Lehman and Brothers which taking advantage of credit derivatives gave massive credits to people with poor income and credit history (subprime credit) and provoked much debate about bank's inherent challenge, the credit management (Mike, 2016).

A survey conducted in Kenya by Owaah (2017) has established that the reasons, much like many banks have been failing recently, are dressed in colorful words like non-performing assets and poor management practices that undermine performance leading to liquidation. In Uganda, the National Bank of Commerce Uganda, (NBCU) went through a dire financial distress from 2010 to 2012 before taken over by Crane Bank Uganda (Uganda Radio Network, 2018). According to BOU (2012), NBCU had incurred continuous losses with half of its loans not performing. Crane Bank has been through a similar situation before being taken over by DFCU bank in late 2016 .

Countries strive to have commercial banks to allow intermediation between people in excess of finance with people in need of funds. Banks trigger investments and impact on the Gross Domestic Products which remains the most used development indicator (Gatuhu, 2013).

The Bank of Uganda, striving for a sound banking sector keeps on track by establishing regulatory reforms. The amendment in January 2016 of Financial Institution Act of 2004 paving a way to the implementation of the capital conservation buffer, Agent Banking, Islamic Banking, the revision of capital requirements and the reform of Deposit Protection Funds. According to Bagyenda 
(2012), a constant assessment of commercial banks is done to ensure safety of depositors.

However, despite all those efforts, the recent case of Crane Bank sends shockwaves through the whole banking sector which according to Kaboyo (2016), had a higher appetite to lend and finance the real estate sector to an extent higher than structured by the Bank of Uganda. The study finds out how various commercial banks credit management indicators affect the financial performance of banks in Uganda. It shows how the inconsistency between what is expected from the banking sector and efforts in place to make sure the channel of funds between people in excess of finance and people in need of finance can lead to banks failures. Therefore, this research attempted to answer the question: What is the effect of credit management to the financial performance of commercial banks in Uganda?

\section{Research Objective}

The general objective of this study was to analyze the effect of credit management to the financial performance of commercial banks in Uganda. Specifically, the study intends to; (i) determine the relationship between credit policy and financial performance of commercial banks in Uganda, (ii) investigate the connection among credit risk control and the financial performance of commercial banks in Uganda, and (iii) establish the relationship between capital adequacy and financial performance of banks in Uganda

\section{Study Hypothesis}

The testable hypotheses were formulated in line with research questions and were subjected to empirical investigation:

$\mathrm{H}_{1}$. There is no significant relationship between the credit policy and the financial performance of commercial Banks in Uganda

$\mathrm{H}_{2}$. There is no a significant influence of the credit risk control on the financial performance of commercial banks in Uganda

$\mathrm{H}_{3}$. There is no significant relationship between capital adequacy ratio and financial soundness of banks in Uganda

\section{REVIEW OF RELATED STUDIES}

\section{Crédit Management}

Bert et al. (2003) define credit management as a process of granting credit, the terms it's granted on and recovering this credit when it's due. This is the function within a bank or company to control credit policies that will improve revenues and reduce financial risks. The Credit Management function incorporates all of a commercial bank's activities aimed at ensuring that customers pay their loans within the defined payment terms and conditions (Kakuru, 2003). Effective Credit Management serves to prevent late payment or non-payment, the two being the greatest risks commercial banks face when conducting their operations. 
According to Nduwayo (2015), the credit management process needs to be understood and followed with adequate checks made on "creditworthiness" of new and existing customers, and 'credit limits' (how much credit is allowed and for how long) must be set. Angelo et al. (2006) add saying that a major responsibility of the credit management function in banks is to ensure credits are collected on time, that any signs a customer might default are acted upon early, and that any overdue credits are "chased" to avoid losses. He concludes that getting the credit management right reinforces the bank's financial or liquidity position, making it a critical component banking. In the current study, credit management involves credit policy, capital adequacy and credit risk control.

\section{Credit Policy}

The credit policy encompasses the settings under which a commercial bank extends credit to its customers and defines organizational desired outcomes of credit activities by governing the actions and procedures to be undertaken to attain that goal (Angelo et al., 2006).

A credit term is a contractual stipulation under which a firm grants credit to customers (Nyawera, 2013), furthermore these terms give the credit period and the credit limit. In the banking industry, they are terms that govern a credit granting. They represent an arrangement between the bank and its customers regarding the expected payment date, any discount offered and the period in which discount is available.

Gurley et al. (1960) define them as standard or negotiated terms (offered by a seller to a buyer) that control the monthly and total credit amount, maximum time allowed for repayment, discount for cash or early payment, and the amount or rate of late payment penalty.

Kakuru (2003) explains the significance of discounts in credit terms. Discounts are offered to induce clients to pay up within the stipulated period or before the end of the credit period. This discount is normally expressed as a percentage of the loan. Discounts are meant to accelerate timely collection to cut back on the amount of doubtful debts and associated costs.

Jackson (2011) observes that credit terms are normally looked at as the terms of discount and the amount of credit and choice of instrument used to evidence credit. Credit terms may include; Length of time to approve loans, this is the time taken from applicants to the loan disbursement or receipt. It is evaluated by the position of the client as indicated by the ratio analysis, trends in cash flow and looking at capital position. Maturity of a loan, this is the time period it takes loan to mature with the interest thereon. Cost of loan. This is interest charged on loans, different banking institutions charge differently basing on what their competitors are charging.

According to the Business Dictionary (2017), a credit collections policy is a document that includes "clear, written guidelines that set the terms and conditions for supplying goods (loan/credit) on credit, customer qualification criteria, procedure for making collections, and steps to be taken in case of customer delinquency". In fewer words, it is a guide offering an organized and repeatable philosophy on selling 
on the rules, regulations and procedures to manage daily operations. The goal for a Credit Plan is to clearly define these elements so that sales and collections employees conform to documented steps and procedures designed to optimize your resources, reduce credit risk, and improve overall cash flow.

Antoine (2015) defines a collection policy as the procedure an institution follows to collect past due account. Collection policy refers to the procedures banking institutions use to collect due accounts. The collection process can be rather expensive in terms of both product expenditure and lost good will (Nyawera, 2013). She continues by saying that collection efforts may include attaching mandatory savings forcing guarantors to pay, attaching collateral assets, courts litigation.

Collection procedure is required because some clients do not pay the loan in time some are slower while others never pay. Thus collection efforts aim at accelerating collections from slower payers to avoid bad debts. Prompt payments are aimed at increasing turn over while keeping low and bad debts within limits (Angelo et al., 2006). However, caution should be taken against stringent steps especially on permanent clients because harsh measures may cause them to shift to competitors. Reicheld et al. (2010) state that collection efforts are directed at accelerating recovery from slow payers and decreases bad debts losses. This therefore calls for vigorous collection efforts. The yardstick to measurement of the effectiveness of the collection policy is its slackness in arousing slow paying customers.

\section{Credit Risk control}

Credit risk control and discipline encompasses a set of ways devised to avoid or lessen the risk of default of an obligator to fully meet their commitments in a timely manner. The management of a credit risk covers: Origination, Loan or debt management, collection and recovery. Thus, according to PWC (2017) credit risk control and discipline encompasses an effective and efficient structures to govern and oversee the organization and achieve the strategy creating synergies between different credit management activities; an increased risk awareness which facilitates better operational and strategic decision-making and an assurance that credit risktaking decisions across the organization are within and aligned to the nature and level of risk that stakeholders in the organization are willing to take.

Ravi, (2012) states that the credit risk control systems are necessary for the assessment of loan application, which then guarantees a bank's total loan portfolio as per the bank's overall integrity (Boyd, 2012). It is necessary to establish a proper credit risk environment, sound credit granting processes, appropriate credit administration, measurement, monitoring and control over credit risk.

\section{Capital Adequacy}

The Basel Accords are three sets of banking regulations (Basel I, II and III) set by the Basel Committee on Bank Supervision (BCBS), which provides recommendations on banking regulations in regards to capital risk, market risk and operational risk. The purpose of the accords is to ensure that financial institutions have enough capital on account to meet obligations and absorb unexpected losses. (Investopedia.com, 2017) 
The Basel Committee on Banking Supervision was founded in 1974 as a forum for regular cooperation between its member countries on banking supervisory matters. The Basel Committee on Banking Supervision describes its original aim as the enhancement of financial stability by improving supervisory knowhow and the quality of banking supervision worldwide. Later on, it turned its attention to monitoring and ensuring the capital adequacy of banks and the banking system. Here below is the Basel broken down: (Bank of International Settlement, 2008)

Basel I was issued in 1988 and focuses on the capital adequacy of financial institutions (Investopedia.com, 2017). The capital adequacy risk (the risk that a financial institution will be hurt by an unexpected loss), categorizes the assets of financial institutions into five risk categories $(0 \%, 10 \%, 20 \%, 50 \%$ and 100\%). Under Basel I, banks that operate internationally are required to have a risk weight of $8 \%$ or more.

Basel II focuses on three main areas: minimum capital requirements, supervisory review of an institution's capital adequacy and internal assessment process, and effective use of disclosure as a lever to strengthen market discipline and encourage sound banking practices including supervisory review. These areas of focus are known as the three pillars.

Basel III: Subsequently to the Lehman Brothers collapse of 2008, the Basel Committee on Banking Supervision decided to update and strengthen the previous accords. In July 2010, an agreement was reached regarding the overall design of the capital and liquidity reform package. This agreement is now known as Basel III. It's a continuation of the three pillars, along with additional requirements and safeguards, including requiring banks to have minimum amount of common equity and a minimum liquidity ratio.

\section{Central Banks}

Bank of Uganda playing the role of a regulator has to some extent a bearing on credit management of commercial banks in Uganda (Kaboyo, 2016). It has instituted several regulatory reforms aimed at improving the soundness of the financial system.

\section{Policies}

According to Weihausen (2017) policies are rules that are made by entities, to achieve their aims and goals. Collins English Dictionary (2018) defines a policy is a set of ideas or plans that is used as a basis for making decisions, especially in politics, economics, or business.

The term may apply to government, private sector organizations and groups, as well as individuals. Presidential executive orders, corporate privacy policies, and parliamentary rules of order are all examples of policy. Policy differs from a regulation or law. While a regulation can compel or prohibit behaviors (e.g. a regulation requiring the payment of taxes on income), policy merely guides actions toward those that are most likely to achieve a desired outcome (Fofack, 2005).

According to Investopedia (2017), policy study may also refer to the process of making important organizational decisions, including the identification of different 
alternatives such as programs or spending priorities, and choosing among them on the basis of the impact they will have. They can be understood as political, managerial, financial, and administrative mechanisms arranged to reach explicit goals. In public corporate finance, a critical accounting policy is a policy for a firm/company or an industry that is considered to have a notably high subjective element, and that has a material impact on the financial statements (Ogilo, 2012).

The financial Insitution Capital Adequacy Policy is a set of aims and goals established by the central bank of Uganda guiding banks on howmuch capital they need to hold to safeguards financial shocks (BOU, 2016). According to the policy Commercial Banks in Uganda should not hold capital less than $12 \%$ of their risk weighted assets.

\section{Regulations}

A regulation is a rule or directive made and maintained by an authority; it has the effect of a law and is considered as a restriction that is imposed by authorities, to make people follow the desired code of conduct (Weihausen, 2017). Bank of Uganda being the regulatory institution in Uganda keeps establishing regulations to ensure the soundness of the financial sector in Uganda.

In that regard, Financial Institutions Act 2004 was amended in January 2016. This has paved way for the implementation by commercial banks of Agent Banking, Islamic Banking, bancassurance, the revision of capital requirements and the reform of the deposit protection fund (DPF). The face of the banking industry in Uganda is set to change after the establishment of islamic banking. Banks in Uganda will have the option to offer alongside with conventional credit offers, an islamic banking based credit offering which market amount to $\$ 2.1$ trillion according to DLA pipper (2017).

Thus, central bank was considered when crafting our conceptual framework as all banks in Uganda craft their credit management in reference to the established Financial Insitution Acts amended 2016 and the Financial Insitution Capital Adequacy Policy 2005.

\section{Financial Performance}

According to Gatuhu (2013), banking performance involves measuring the results of the bank's policies and operations in both monetary and non-monetary terms. Turyahebwa (2013) defines performance in financial sector as the ability to operate efficiently, profitably, survive, grow and react to the environmental opportunities and threats. In agreement with this, Pandey (2003) assert that, banks performance is measured by how efficient the enterprise is in use of resources in achieving its objectives.

Investopidia (2017) defines financial performance as a subjective measure of how well a firm can use assets from its primary mode of business and generate revenues. The term is also used as a general measure of a firm's overall financial health over a given period of time, and can be used to compare similar firms across the same industry or to compare industries or sectors in aggregation. 
There are many different ways to measure financial performance, but all measures should be taken in aggregation. Line items such as revenue from operations, operating income or cash flow from operations can be used, as well as total unit sales. Furthermore, the analyst or investor may wish to look deeper into financial statements and seek out margin growth rates or any declining debt (Tucker, 2004). The business dictionary (2017) stipulates that financial performance in broader sense refers to the degree to which financial objectives being or has been accomplished and is an important aspect of finance risk management. It is the process of measuring the results of a firm's policies and operations in monetary terms. It is used to measure firm's overall financial health over a given period of time and can also be used to compare similar firms across the same industry or to compare industries or sectors in aggregation. In the context of this study, the return on equity was used to capture the financial performance of commercial banks in Uganda.

\section{Return on Equity}

The return on equity (ROE) used in the present study to assess financial performance is defined as the ability of the management to generate a return out the equity entrusted to them by owners was be used to proxy the financial performance of commercial banks (Alin et al., 2009).

The return on equity is computed by the ratio on net income to shareholders' equity. It is a measure of profitability that calculates how many dollars of profit a company generates with each dollar of shareholders' equity (Pasiouras \& Kosmidou, 2014)

\section{Empirical Review}

Credit risk management in banks has become more important not only because of the financial crisis that the world has experienced in the past but also with the introduction of Basel (I/II \& III). Since granting credit is one of the main sources of income in commercial banks, the management of the risk related to that credit affects the performance of banks. In this section, we describe empirical researches done by various scholars on credit management in the financial sector.

Following the guidelines on proposal writing of University of Nairobi, we reviewed the literature both by thematic and as per assigned objective of the study as enumerated in the previous chapter.

\section{Credit Policy and Financial Performance}

Credit policy encompasses both the credit terms and the collection policy set up by the organization to attain its goals (Antoine, 2015). In this subtheme, we review authors who have addressed the relationship between credit policy and financial performance of banking institutions in the past.

Pamela (2012) sought to examine to what extent the credit terms and access to credit have affected financial performance in SMEs in Uganda, the results indicated a significant positive association among the variables of credit terms. She concluded that credit terms contribute $33.1 \%$ of the variance in financial performance. 
International Journal of Business and Management Review

Vol.8, No.5, pp.68-99, August 2020

Published by ECRTD-UK

Print ISSN: 2052-6393(Print), Online ISSN: 2052-6407(Online)

Arora, (2013) attempted to identify the factors that contribute to Credit Risk analysis and performance in Indian banks. He revealed that credit worthiness analysis and Collateral requirements are the two important factors for when analyzing credit risk in the Indian Banking sector. The results also indicate that there is significant correlation between the credit risk management and the performance of Banks in India.

Olawale (2015) suggested that management need to be cautious in setting up a collection policy that will not negatively affects profitability and also they need to know how a collection policy affects the operation of their banks to ensure judicious utilization of deposits and maximization of profit. He concluded that improper credit risk management reduce the bank profitability, affects the quality of its assets and increase loan losses and non-performing loan which may eventually lead to financial distress. Kargi (2011) cited in Kolapo et al (2012) attained to the same conclusions in a study conducted in Ghana.

\section{Credit Risk Control and Financial Performance}

Ogilo (2012) analysed the impact of credit risk management on the financial performance of commercial banks and also attempted to establish if there exists any relationship between the credit risk management determinants by use of CAMEL (capital adequacy, asset quality, management efficiency and liquidity) indicators and financial performance of commercial banks in Kenya. The study found out that there is a strong impact between the CAMEL components on the financial performance of commercial banks. It was also established that the CAMEL had weak relationship with financial performance (ROE) whereas earnings had a strong relationship with financial performance. This study concludes that CAMEL model can be used as a proxy for credit risk management. Nzioka (2013) attained to same conclusions in a study conducted on 43 commercials banks in Kenya using the ROA as a profitability proxy and total deposits, total loan and total assets as explaining variables.

\section{Capital Adequacy and Performance}

An excess of studies has examined the connection between international credit standards (capital adequacy) and bank performance for different countries. Capital adequacy in line with the international credit standard is the ability to meet up with the Basel targets in term of capital reserve, lending to primary sectors and improvement in the employee's performance (Chinonye et al., 2010).

According to Paul (2002), the inadequacy of minimum capital is a major cause of bank failure in Uganda. Paul's research were however not so conclusive on whether the new capital requirements played a part in setting off or precipitating the crisis that took place in the late 90 s in Uganda.

Using Capital adequacy as one of independent variables, Waithaka (2013), concluded that the compliance with BASEL II accords has improved the Kenyan commercial's bank lending with the overall impact on their performance. In a research done in Tunisia, Ines G. (2016) using GMM dynamic model estimation found that capital adequacy and operational efficiency strongly influences the credit risk in 10 Tunisian commercial Banks with an overrall impact on their profitability. 
Using World Bank Basel Core Principles for Effective Bank Supervision (BCP) assessments conducted from 1999 to 2010, Ayadi et al.., (2015) evaluated how compliance with Basel Core Principles affects bank performance for a sample of 863 publicly listed banks drawn from a broad cross-section of countries. Their results indicated that overall BCP compliance, or indeed compliance with any of its individual chapters (Capital adequacy being one of them), has no association with bank efficiency (performance).

\section{Research Gaps}

The research completes similar studies conducted in various countries: Oludhe (2011) who studied credit risk management and financial performance of banks in Kenya, Uwalomwa (2015) in his attempt to establish the relationship between credit management and financial performance of 10 listed banks in Nigeria and Nduwayo (2015) who sought to understand the connection between loan management and financial performance of commercials banks in Rwanda both of them did not clearly establish the relationship of international standards concerning banks' capital management as instituted by the bank of international settlement and applicable in Uganda and many countries worldwide for the sake of financial performance of commercial banks.

To the best of my knowledge, most of the studies conducted in Uganda in the arena of credit management and financial performance were survey studies concerning microfinance institutions overlooking the banking sector which is the most important part of the financial system in the country. This research filled that glaring gap in assessing the impact of credit management to performance of commercial banks in Uganda.

\section{CONCLUSION}

Credit management issues in the banking sector do not only have greater impact on bank performance but also on national economic growth and general business development. The bank's motivation for credit management comes from those risks which can lead to underperformance. (Adeusi et al, 2013)

Risk exposure in banking system has increased due to fierce competition, changing socioeconomic patterns, market flexibility, and increased foreign exchange business and cross border activities. These developments have resulted into various types of banking risks. Credit risk, earlier present in the banking system has also increased and Credit risk analysis has emerged as a big challenge for commercial banks as almost all empirical studies have established a strong correlation between credit risk management and financial performance of commercial banks.

This research has brought new ideas in the area of credit management and performance of commercial banks as no other study has done that. It has focused on the impact of credit policy, credit risk control and credit standards (capital adequacy) on the financial performance of commercial banks in Uganda. Apart from the capital adequacy ratio, no research in the reviewed literature has emphasized on the application of international standards (capital adequacy) on the financial performance of commercial banks in Uganda. Moreover, most studies on credit management are survey studies focused on microfinance institutions, so the study 
International Journal of Business and Management Review

Vol.8, No.5, pp.68-99, August 2020

Published by ECRTD-UK

Print ISSN: 2052-6393(Print), Online ISSN: 2052-6407(Online)

helped fill that glaring gap by trying to understand the relationship between credit management and financial performance in the context of Uganda.

\section{RESEARCH METHODOLOGY}

\section{Research Design}

This research problem was studied through the use of causal research design. Causal research deals with cause-effect relationship. In causal research design, the emphasis is on specific objectives about the effects of changes of one variable on another variable and it involves an experiment where an independent variable is changed or manipulated to see how it affects a dependent variable (Saunders, 2003). Causal research design was useful in this study since it enabled the researcher to examine the impact on the dependent variable from variations in the independent variables.

\section{Study Population}

Target population can be understood as a set of individual or entities meetings the particular criterion specified for a research investigation (Alvi, 2016). Nduwayo (2015), defines a population as the total number of items in a specified field of inquiry and he added that population is an asset of cases about which one wishes to draw some conclusions. Therefore, the targeted population for this study is composed of all registered commercial banks and operational in Uganda whose number is 24 as of today (Bank of Uganda, 2017).

\section{Determinants of the Sample Size}

The sample size measures the number of individual samples measured or observations used in a survey or experiment (Angelo et al., 2006). As the study used a universal sampling technique there was no need to determine the sample as all banks were considered and studied in the present research.

\section{Sampling Techniques and Procedures}

The study used universal sampling techniques, where all the banks licensed and operational in Uganda were selected as sample size, because it was easy for the researcher to reach and analyze every one of their audited financial statements. Thus, given the size of the population there was no need to find out a sample size from the population, the sample size equal to the population. This is in accordance with Nduwayo (2015) who used a similar sampling technique in a study conducted in Rwanda.

\section{Data Collection Methods}

The research used secondary data based on respective banks' audited financial statements and Bank of Uganda annual supervision reports for the period under analysis 2012-2017. Secondary data can be defined as data collected by others, not specifically for research question at hand (Jackson, 2011). Oludhe (20111) defines secondary data as data which is collected by someone who is someone other than the user. 
The researcher opted for secondary data analysis to save time that would otherwise be spent collecting data and, particularly in this case of quantitative data, secondary data provided us larger and higher-quality databases that would be unfeasible for any individual researcher to collect on his own. In addition, analysts of social and economic change consider secondary data essential, since it is impossible to conduct a new survey that can adequately capture past change and/or developments (Mohd \& al., 2010).

\section{Data Collection Instruments}

Data collection instrument refers to the device used to collect data, such as a paper questionnaire or computer assisted interviewing system (Kristianti, 2016). Alvi (2016) adds that it is the general term that researchers use for a measurement device when conducting a research.

BOU annual supervision reports and audited financial reports of banks were analyzed to get a firm grasp on how banks have financially performed the last 6 years in Uganda. A sample of extracted financial results were attached in the appendix to support the results in chapter four.

\section{Data Validity and Reliability}

The reliability of a research instrument concerns the extent to which the instrument yields the same results on repeated trials. Although unreliability is always present to a certain extent, there is generally a good deal of consistency in the results of a quality instrument gathered at different times. The tendency toward consistency found in repeated measurements is referred to as reliability. (Gatuhu, 2013)

One method of testing for reliability is the internal consistency method. The internal consistency method provides a unique estimate of reliability for the given test administration.

The most popular internal consistency reliability estimate is given by Cronbach's alpha. It is expressed as $\alpha=\mathrm{Np} /[1+\mathrm{p}(\mathrm{N}-1)]$ Where $\mathrm{N}$ equals the number of items and $\mathrm{p}$ equals the mean inter-item correlation. The Internal consistency method was used to assess the reliability of our research instrument.

SSPSS 20 was used to execute Cronbach's alpha reliability test:

Reliability Statistics

\begin{tabular}{|r|r|}
\hline $\begin{array}{c}\text { Cronbach's } \\
\text { Alpha }\end{array}$ & N of Items \\
\hline 0,67 & 4 \\
\hline
\end{tabular}

Source: SPSS 20

The alpha coefficient for the four items was 0.67 suggesting that the items have relatively high internal consistency.

The validity is a judgment of how appropriate the instruments seem to a panel of reviewers who have knowledge of the subject matter (Alvi, 2016). ResearchGate which is a platform allowing researcher around the world collaborate helped us to have opinion on a panel of reviewers from around the world. 5 researchers on 
Research-Gate judged appropriate audited financial reports (as according to IFRS) to assess the relationship between credit management and performance of commercial banks.

\section{Procedures of Data Collection}

The researcher got an authorization from the University which granted him a letter of authority to proceed to the field. He sought to get approvals from banks under study which made the research possible by availing audited financial reports. Subsequent to that, the investigator himself collected secondary data from audited financial statements and publications from the central bank.

\section{Data Analysis Techniques}

After the data collection exercise, descriptive statistics were easily analyzed using frequency counts, percentages or averages. They were classified, tabulated and analyzed by applying percentages and inferential statistical test, whenever necessary tables and charts were presented showing analysis of data and this result of quality information. As in accordance with Uwalomwa et al. (2015), the multiple linear regression was used in data analysis which could be termed to be a statistical technique used to find relationships between variables for the purpose of predicting future values. The Statistical Package for Social Sciences (SPSS 20) software was used to help us go through data analysis.

\section{Measurements of Variables}

The data analysis method used was based on Pearson correlation analysis and a multiple regression model this is in agreement with Sharma (2012). A multiple linear regression model was used since it enables the prediction of one variable on the basis of several other variables. The multiple regression model took the form of: $Y=F(x)$

$$
Y=\alpha+\beta_{1} X_{1}+\beta_{2} X_{2}+\beta_{3} X_{3}+e
$$

\section{Ethical Considerations}

In every research conducted it is necessary to follow ethical requirements, according to Bryman \& Bell (2007), they defined Ethics as codes and conducts which researchers follow in research work. The researcher endeavored to maintain a high ethical standard throughout the study. Ethical issues cannot be ignored because they relate directly to the integrity of the research, the appropriate citation and referencing was followed throughout the study to avoid plagiarism, the central banks and commercial banks were contacted to ensure their approvals and cooperation, a letter of authority was received from the University to allow the student proceeds with data collection. In the study, the researcher was responsible to ensure that all the ethical matters are followed. 


\section{PRESENTATION, ANALYSIS AND INTERPRETATION OF RESEARCH Findings, Summary of Statistics}

Both descriptive and inferential statistics were employed specifically using regression and ANOVA to establish the significance /fitness of the model and also to establish the link between credit management and financial performance of commercial banks in Uganda.

\section{Descriptive Statistics}

Descriptive statistics for the variables in the study are shown using charts and table.

We used line charts to present time series of data related to components of credit management (credit policy, capital adequacy and credit risk control) and the performance (Return On Equity) of commercial banks in Uganda.

\section{Figure 1. Average lending ratio of commercial banks in Uganda for the last 6} years

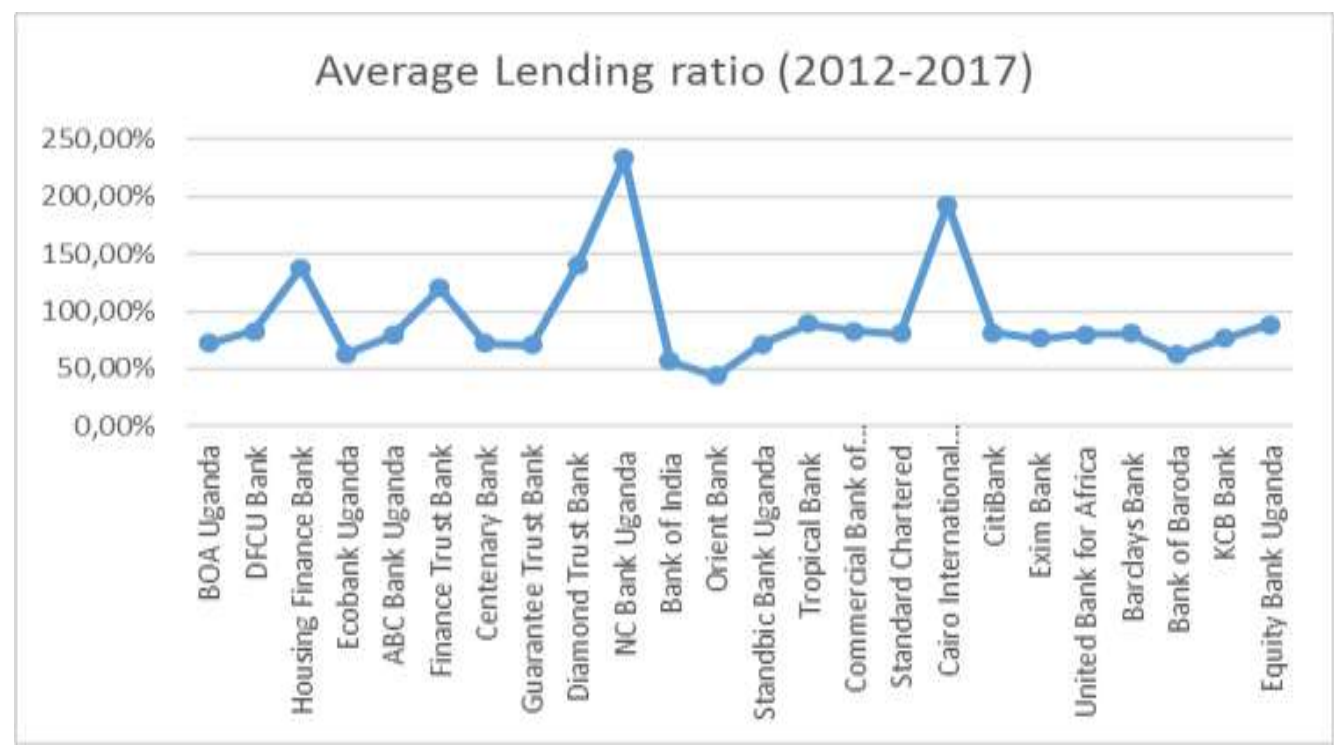

Source: Researcher's investigations

As show on figure 1, most banks in Uganda lend less than what they receive in terms of customers deposits. NC Bank Uganda was the bank with the highest lending ratio amounting to more than 200\%. On the other hand, Orient Bank was the bank with the lowest lending ratio that averaged a bit less than $50 \%$ for the 6 years under study.

Figure 2. Average Capital Adequacy ratio for licensed commercial banks in Uganda for the past six years 


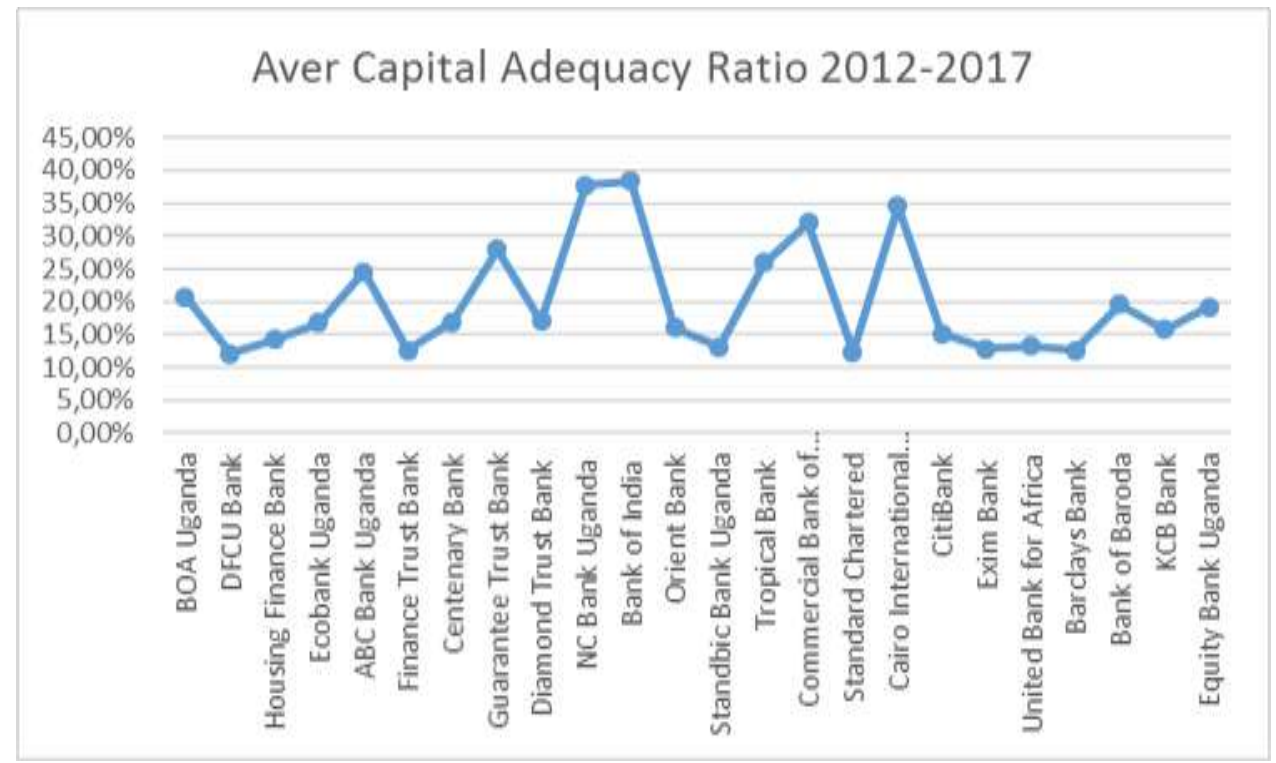

Source: Researcher's investigations

As shown on figure 2 above, for the period under study, banks in Uganda had an average capital adequacy ratio above the required 12\%. NC Bank Uganda and Bank of India were the most liquid with the highest average capital adequacy respectively $38 \%$ and $39 \%$.

Figure 3. Average NPL to TL ratio of commercial banks in Uganda (2012-2017)

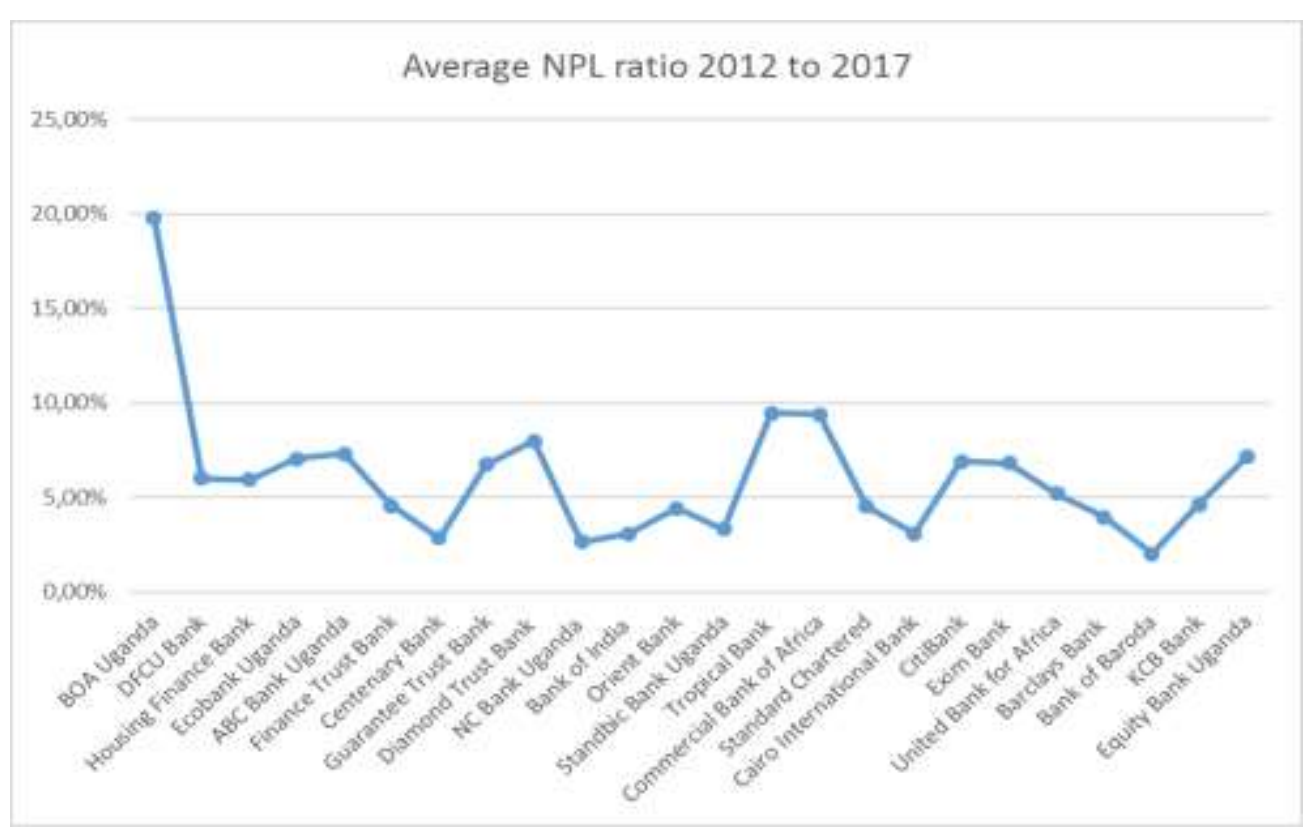

Source: Researcher's investigations

As shown on figure 3 above, BOA Uganda had the greatest average ratio of nonperforming loan (20\%) followed by Tropical Bank and Commercial Bank of Africa that had slightly less than $10 \%$ of their loans nonperforming. Bank of Baroda had the least ratio of nonperforming loans $(>2.5 \%)$ in the sector 
Figure 4. Average ROE of commercial banks in Uganda (2012-2017)

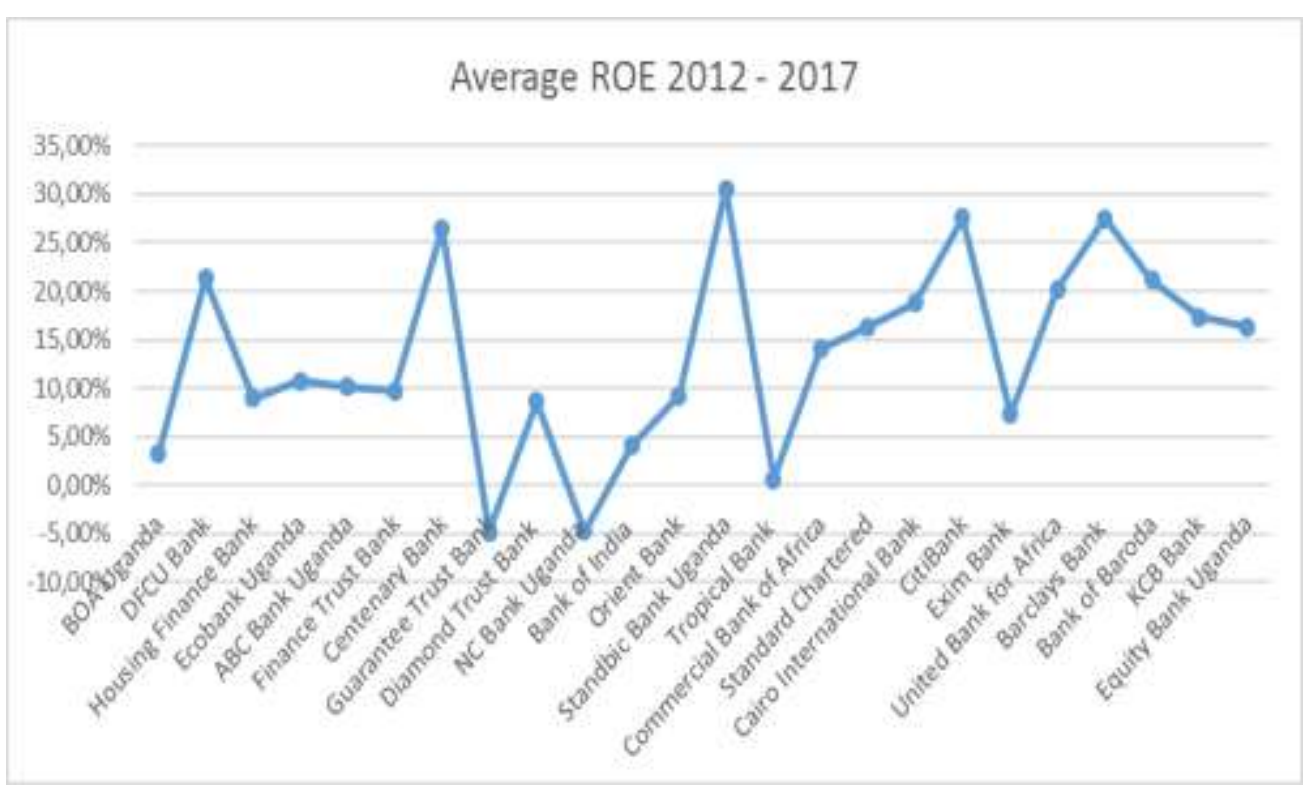

Source: Researcher's investigations

As shown on figure 4, Standbic Bank is the bank with highest average ROE amounting to $30 \%$ for the period under study. Only two out of 24 licensed commercial banks had a negative average return on equity, namely Guarantee Trust Bank and NC Bank Uganda (-5\% each)

\section{Inferential Statistics}

\section{Model specifications}

Table 1. Summary of statistics

\begin{tabular}{|l|r|r|r|r|r|r|}
\hline & \multicolumn{1}{|c|}{$\mathrm{N}$} & Minimum & Maximum & \multicolumn{1}{c|}{ Mean } & $\begin{array}{c}\text { Std. } \\
\text { Deviation }\end{array}$ & Variance \\
\cline { 2 - 7 } & Statistic & Statistic & Statistic & Statistic & Statistic & Statistic \\
\hline $\begin{array}{l}\text { Lending } \\
\text { ratio }\end{array}$ & 24 & .44 & 2.33 & .9299 & .43578 & .190 \\
\hline CAR & 24 & .12 & .38 & .2006 & .08409 & .007 \\
\hline NPL & 24 & .02 & .20 & .0603 & .03604 & .001 \\
\hline ROE & 24 & -.05 & .31 & .1335 & .09864 & .010 \\
\hline
\end{tabular}

Source: Extracted by the researcher from audited financial reports (secondary data)

Results from our descriptive statistics as shown on the table 1 presents an average ROE of $13.35 \%$ for all the banks in the industry in the period under study. Correspondingly, the independent variables in this study proxied as (Lending ratio, CAR and NPL/TL) maintains an averaged mean distribution value of about $92.99 \%$, $20 \%$ and $6 \%$ respectively for the whole banks in the industry. Also, findings from the Pearson correlation analysis as depicted in table 2 indicates that the independent 
variables (LR, CAR \& NPL/TL) have both a negative association (respectively $23.6 \%, 52.5 \%$ et $33.8 \%$ ) with the performance (ROE) of the sampled banks.

Table 2. Correlation coefficient between independent and dependent variables

\begin{tabular}{|c|c|c|c|c|c|}
\hline & & $\begin{array}{l}\text { Lending } \\
\text { ratio }\end{array}$ & CAR & NPL & ROE \\
\hline $\begin{array}{l}\text { Lending } \\
\text { ratio }\end{array}$ & $\begin{array}{l}\text { Pearson } \\
\text { Correlation }\end{array}$ & 1 & .404 & -.177 & -.263 \\
\hline & Sig. (2-tailed) & & .050 & .409 & .215 \\
\hline & $\mathrm{N}$ & 24 & 24 & 24 & 24 \\
\hline CAR & $\begin{array}{l}\text { Pearson } \\
\text { Correlation }\end{array}$ & .404 & 1 & -.010 & $-.525^{* *}$ \\
\hline & Sig. (2-tailed) &, 050 & & ,961 & .008 \\
\hline & $\mathrm{N}$ & 24 & 24 & 24 & 24 \\
\hline NPL & $\begin{array}{l}\text { Pearson } \\
\text { Correlation }\end{array}$ & -.177 & -.010 & 1 & -.338 \\
\hline & Sig. (2-tailed) & .409 & .961 & & .106 \\
\hline & $\mathrm{N}$ & 24 & 24 & 24 & 24 \\
\hline ROE & $\begin{array}{l}\text { Pearson } \\
\text { Correlation }\end{array}$ & -.263 & $-.525^{* *}$ & -.338 & 1 \\
\hline & Sig. (2-tailed) & .215 & .008 & .106 & \\
\hline & $\mathrm{N}$ & 24 & 24 & 24 & 24 \\
\hline
\end{tabular}

Source: Extracted by the researcher from audited financial reports (secondary data)

Table 2 shows the relationship between the dependent and independent variables. As can be seen from the Table capital ratio is negatively related $(52.5 \%$ with a probability of 0.008 ) to ROE; this is in line with the conventional argument that higher capital ratios encourage banks to invest in safer assets, such as lower-risk loans or securities, which may affect bank performance (Okoth et al., 2013). Credit risk control which is expressed as non-performing loans to total loans is negatively related (33.8\% with a probability of 0.106 ) to banks performance indicator (ROE). This indicates that poor asset quality or high nonperforming loans to total asset is related to poor bank performance. The other explanatory variable, lending ratio is negatively related $(26.3 \%$ with a probability of 0.215$)$ to the performance as provided by ROE, but the relationship is very weak. 


\section{Model Assumptions:}

The following diagnostic tests were carried out to ensure that the data suits the basic assumptions of a linear regression model: We checked for normality using descriptive statistics. Kurtosis and Skewness of the distribution of the data were examined. The study had an average skewness and kurtosis coefficients of respectively 1.408 and 3.208 , both figures are superior to their standard errors of respectively 0.472 and 0.917 multiplied by 3 (Gaskin, 2018). Thus, the variables are closed to a normal distribution. Multi-collinearity was tested through the assessment of the existence of strong correlation between the independent variables using Variance Inflation Factor (VIF) and correlation coefficient, this is in accordance with Jackson (2011). As shown on table 3, the values of tolerance were greater than 0.1 and those of VIF less than $10,1.239 ; 1.201 \& 1.037$ respectively for Lending Ratio, CAR and NPL/TL. Thus, there is no serious problem of multi-collinearity in the study. To avoid the problem of heteroscedasticity of disturbance terms, weighted Generalized Least Square (GLS) was employed in establishing the relationship.

Table 3. Variable Inflation Factor

\begin{tabular}{|l|c|c|}
\hline & $\begin{array}{c}\text { Tolera } \\
\text { nce }\end{array}$ & \multicolumn{1}{c|}{ VIF } \\
\hline $\begin{array}{l}\text { Lending } \\
\text { ratio }\end{array}$ & .807 & 1.239 \\
\hline CAR & .833 & 1.201 \\
\hline NPL & .964 & 1.037 \\
\hline
\end{tabular}

Table 4. Summary of coefficients 2012-2017

\begin{tabular}{|c|c|c|c|c|c|c|c|c|}
\hline \multirow{2}{*}{\multicolumn{2}{|c|}{ Model }} & \multicolumn{2}{|c|}{$\begin{array}{c}\text { Unstandardized } \\
\text { Coefficients }\end{array}$} & \multirow{2}{*}{$\begin{array}{c}\text { Standardized } \\
\text { Coefficients } \\
\text { Beta }\end{array}$} & \multirow[t]{2}{*}{$\mathrm{T}$} & \multirow[t]{2}{*}{ Sig. } & \multicolumn{2}{|c|}{$\begin{array}{c}95,0 \% \\
\text { Confidence } \\
\text { Interval for B }\end{array}$} \\
\hline & & B & $\begin{array}{l}\text { Std. } \\
\text { Error }\end{array}$ & & & & $\begin{array}{l}\text { Lower } \\
\text { Bound }\end{array}$ & $\begin{array}{l}\text { Upper } \\
\text { Bound }\end{array}$ \\
\hline \multirow[t]{4}{*}{1} & (Constant) & .334 & .059 & & 5.642 & .000 & .211 & .458 \\
\hline & $\begin{array}{l}\text { Lending } \\
\text { ratio }\end{array}$ & -.031 & .043 & -.136 & -.712 & .485 & -.121 & .060 \\
\hline & CAR & -.555 & .221 & -.473 & -2.511 & .021 & -1.016 & -.094 \\
\hline & NPL & -1.005 & .479 & -.367 & -2.098 & .049 & -2.005 & -.006 \\
\hline
\end{tabular}

a. Dependent variable ROE

Source: output from SPSS based on data from extracted financial reports of banks

Table 4 above presents the coefficients of the variables, the significance of those coefficients and the standard error term. As per the SPSS generated table 4, the equation, $\mathrm{Y}=\alpha+\beta 1 \mathrm{X} 1+\beta 2 \mathrm{X} 2+\beta 3 \mathrm{X} 3+\varepsilon$

Becomes;

$\mathrm{Y}=0.334-0.031 \mathrm{X} 1-0.555 \mathrm{X} 2-1.005 \mathrm{X} 3+0.059$ 
The results indicate that there is a negative relationship between credit management as measured by LR, CAR and NPL/TL ratio with financial performance measured by ROE. This indicates that banks in Uganda can increase their financial performance by reducing their non-performing loans which is heavily correlated to performance i.e. increasing the quality of their credit standards.

Moreover, the table depicts that holding the lending ratio, the capital adequacy ratio and the ratio of nonperforming loans to total loans constant, the performance of banks in Uganda will be 0.334 . It also shows that a unit decrease in lending ratio will lead to an increase in financial performance by 0.031 , a unit decrease in capital adequacy ratio will lead to an increase in financial performance by 0.555 and a unit decrease in the ratio of nonperforming loans to total loans will lead to an increase in financial performance by 1.005 .

Table 5. Analysis of variance statistics for 2012-2017 data (ANOVA)

\begin{tabular}{|l|l|r|r|r|r|r|}
\hline \multicolumn{2}{|l|}{ Model } & $\begin{array}{c}\text { Sum of } \\
\text { Squares }\end{array}$ & \multicolumn{1}{c|}{ df } & $\begin{array}{c}\text { Mean } \\
\text { Square }\end{array}$ & F & Sig. \\
\hline \multirow{2}{*}{1} & Regression & .091 & 3 & .030 & 4.602 & $.013^{\alpha}$ \\
\cline { 2 - 7 } & Residual & .132 & 20 & .007 & & \\
\cline { 2 - 7 } & Total & .224 & 23 & & & \\
\hline
\end{tabular}
a. Dependent Variable: ROE
b. Predictors: (Constant), NPL, CAR, Lending ratio

Source: output from SPSS based on data from extracted financial reports of banks

The researcher used 5\% significant level indicating that there is a risk of only $5 \%$ of being wrong when accepting or rejecting our null hypothesis.

The table 5 above shows that the mean of the independent variables (LR, CAR and NPL/TL) are not equal. This is because the P-value is 0.013 is less than the significance level of 0.05

\subsubsection{Model Summary}

Table 6. Summary of the regression model

\begin{tabular}{|c|c|c|c|c|c|c|c|c|c|c|}
\hline \multirow[t]{2}{*}{ Model } & \multirow[t]{2}{*}{$\mathrm{R}$} & \multirow{2}{*}{$\begin{array}{c}\mathrm{R} \\
\text { Square }\end{array}$} & \multirow{2}{*}{$\begin{array}{c}\text { Adjusted } \\
\text { R } \\
\text { Square }\end{array}$} & \multirow{2}{*}{$\begin{array}{c}\text { Std. } \\
\text { Error of } \\
\text { the } \\
\text { Estimate }\end{array}$} & \multicolumn{5}{|c|}{ Change Statistics } & \multirow{2}{*}{$\begin{array}{l}\text { Durbin- } \\
\text { Watson }\end{array}$} \\
\hline & & & & & $\begin{array}{c}\mathrm{R} \\
\text { Square } \\
\text { Change }\end{array}$ & $\begin{array}{c}\mathrm{F} \\
\text { Change }\end{array}$ & df1 & df2 & $\begin{array}{c}\text { Sig. F } \\
\text { Change }\end{array}$ & \\
\hline 1 & $.639^{\mathrm{a}}$ & .408 & .320 & .08136 & .408 & 4.602 & 3 & 20 & .013 & 2.390 \\
\hline
\end{tabular}

a. Predictors: (Constant), NPL, CAR, Lending ratio

b. Dependent Variable: ROE

Source: output from SPSS based on data from extracted financial reports of banks

According to the F statistics above the variables used in the model fits well in the model. The model shows that the LR, CAR and NPL/TL ratio combined have a 
International Journal of Business and Management Review

Vol.8, No.5, pp.68-99, August 2020

Published by ECRTD-UK

Print ISSN: 2052-6393(Print), Online ISSN: 2052-6407(Online)

significant relationship $(\mathrm{R}=0.639, \mathrm{P}=0.013)$ with performance. It is also shows that they can predict up to $40.8 \%$ of the variance in performance.

\section{Interpretation of Findings}

The purpose of this study was to examine the effects of credit management on financial performance of banking institutions in Uganda. Specifically, the study established whether there is a relationship between lending ratio and financial performance; Capital Adequacy Ratio and financial performance and ratio of Nonperforming Loans to Total Loans and financial performance. Regression analysis was used in analyzing data to achieve the study objectives.

Table 1 represents the summary statistics computed using the statistical package for social sciences (SPSS). From the output, the number of years for the study is six (6). The results show that the maximum, minimum, standard deviation, mean and variance of the variables credit policy, capital adequacy, credit risk control and financial performance of banking institution's industry as a whole for the six years studied. The mean lending ratio for industry was established to $92.99 \%$ while the average CAR stood at $20.06 \%$ high above the required $12 \%$ by the central banks. This implies that Banks in Uganda holds more capital than they should in respect of the regulation. No banks had an average CAR below the required as the minimum CAR for the period under study was $12 \%$ while the maximum was $38 \%$. The ratio of nonperforming loans was in average $6.03 \%$, this translates into the sound banking sector we have in Uganda with an average ROE of $13.35 \%$ with the best performing banks hitting as much as $31 \%$.

Table 2 shows the relationship between the dependent and independent variables. As can be seen from the Table, Lending ratio, Capital Adequacy Ratio and the ratio of NPL/TL are all negatively related to ROE. Capital Adequacy Ratio has a significant negative relationship with ROE; this is in line with the conventional argument that higher capital ratios encourage banks to invest in safer assets, such as lower-risk loans or securities, which may affect bank performance (Bouwman, 2009). Credit risk control which is expressed as non-performing loans to total loans is also negatively related to the banks performance indicator (ROE). This indicates that poor asset quality or high nonperforming loans to total loans is related to poor bank performance. The negative correlation coefficient between poor asset quality and return on equity is significant $(33.8 \%)$. This is due to the fact that loan constitutes the largest share of assets that generate income for the investment (equity). The other explanatory variable lending ratio is also negatively related to ROE.

Table 3 refers to testing if our independent variables in our multiple regression analysis are closely correlated to one another. It's one of basic assumptions that needs to be verified when conducting a regression analysis (Investopedia.com, 2018).

As shown on table, the values of tolerance were greater than 0.1 and those of VIF less than 10, 1.239; $1.201 \& 1.037$ respectively for Lending Ratio, CAR and NPL/TL. Thus, there is no serious problem of multi-collinearity in the study.

Table 4 summarizes the coefficients of the variables. According to the regression equation established, taking all factors (credit policy, capital adequacy and Credit Risk Control) constant, the financial performance of the banks as a result of the 
independent factors will be 0.334 . This regression model shows that all factors have a negative relation in the financial performance of banking institutions in Uganda. The error term amounts to a positive figure of 0.059 which is the standard error accepted for the factor (independent factors) to be considered effective in controlling financial performance of banking institutions.

The results from the coefficients summary indicate that significance of coefficients of credit policy (LR), capital adequacy (CAR) and Credit Risk Control (NPL/TL) are $-0.031,-0.555$ and $-1,005$ respectively. The significance of coefficients range is 0.02 to 0.50 , whereby the coefficients closer to 0.02 indicate how strongly the results are significant and those close to 0.5 indicate less significance of findings. It therefore implies that both the CAR and the NPL/TL are significant though have an impact at different significance i.e. capital adequacy and Credit Risk control have a greater impact compared to Credit policy (LR) on the financial performance of Banks. The deduction on the standard error covers a level of up to 0.059 ; whereby the credit policy (LR) has an error of 0.043 , capital adequacy (CAR) of 0.221 and the credit risk control (NPL/TL) has an error of 0.479 .

Table 5. Analysis of variances in its column of sum of squares represents the amount of the total sum of squares in the dependent variable that is not explained by the least squares regression line. SPSS refers to sum of squares error as sum of squares residual error. Thus of the total sum of squares that is explained by the regression line this regression model leave 0.132 unexplained. The results show that the researcher faced a risk of only $1.3 \%$ or 0.013 to attain to wrong conclusions.

The model summary in table 6 contains R-square representing the proportion of the variability in one series that can be explained by the variability of one or more series in a regression model. The table illustrates the $\mathrm{R}$ value for the model. $\mathrm{R}^{2}$ measures correlation between the dependent and the independent variables. $\mathrm{R}^{2}$ is therefore a statistic measurement that provides information about fitness of a model. The higher the value of $\mathrm{R}^{2}$ the better is the fitness of a model. The value of $\mathrm{R}^{2}$ is between 0 and $100 \%$. If $\mathrm{R}^{2}$ is $1(100 \%)$, the regression line perfectly fits the data and vice-versa. $\mathrm{R}^{2}$ is $40.8 \%$ implying that there is a low percentage that the line perfectly fits the data.

Coefficient of determination, $\mathrm{R}$ squared also explains the extent to which changes in the dependent variable can be explained by the change in the independent variable or the percentage of variation in the dependent variable (financial performance) that is explained by independent variables (credit policy, capital adequacy and Credit risk control). The three independent variables that were studied explain only $40.8 \%$ of the relationship between independent variables (credit policy, capital adequacy and credit risk control) and the dependent variable (financial performance). This therefore means that other factors not studied in this research contribute $59 \%$ of the financial performance of Banking Institutions in Uganda. Therefore, further studies should be conducted to investigate the other factors that affect financial performance of Banks in Uganda.

The adjusted $\mathrm{R}$ square also called the coefficient of multiple determinations is the percent of variance in the dependent explained uniquely or jointly by the dependent variable. The findings further indicate that adjusted overall $\mathrm{R}$-squared was 0.320 
meaning that the regression line explains $32 \%$ of financial performance (dependent variable). The changes are caused by the independent variable included in the regression line. Therefore, error term or the residual account for the other factors is $68 \%$. This means that there is no strong relationship between financial performance and chosen credit management indicators (credit policy, capital adequacy and credit risk control). ANOVA $F$ has a statistic of 4.602 significant with a $\mathrm{P}$-value $=0.01$. It was evident from the study that the three variables are individually significant but in a small proportion.

\section{Hypothesis testing}

A statistical hypothesis was conducted to confirm or reject the established testable hypothesis of the study. According to Çomakoğlu (2017), a hypothesis is proposed for the statiscal relationship between the two data sets and that should be compared as alternative to an idealized null hypothesis that proposes no relationship between two data sets.

The significance level of the study was $5 \%$, based on the table 4 , the null hypothesis will be rejected for all credit management indicators having a $\mathrm{P}$-value less than the chosen significance threshold; this is in accordance with Adeusi et al. (2013) in a similar study done in Nigeria.

H1. The first testable hypothesis in the study was : There is no significant relationship between credit policy and performance of commercial bank. As per findings in the table 4 , the credit policy captured by the lending ratio had a pvalue equals to 0.485 and far above the proposed significance level (0.05). Thus we accept the H0, there is no significant relationship between the credit policy and the the performance of commercial banks in Uganda.

H2. The second testable hypothesis in the study was: There is no significant relationship between the capital adequacy ratio and the performance of commercial banks. As per findings, CAR had p-value equals to 0.021 and less than the chosen level of significance (0.05). Thus we reject the $\mathrm{H} 0$ and accept the alternative on; there is significant relationship between the CAR and the performance of commercial banks.

H3. The third testable hypothesis in the study was: There is no significant relationship between the credit risk control and performance of commercial banks. We found that the credit risk control captured by the nonperforming loan ratio had a p-value of 0.049 which is less than the level of significance chosen under the study. Thus, we reject the $\mathrm{H} 0$ and accept the alternative one. There is a significant relationship between the credit risk control and the performance of commercial banks in Uganda.

When a probability value is below the signifcance level, the effect is statistically significant and the null hypothesis is rejected, thus the alternative hypothesis is accepted; this is exactly what happened whith $\mathrm{H} 2$ and $\mathrm{H} 3$ when their respectives pvalue were less that the level of significance chosen under the present study. However, in accepting the alternative hypothesis for $\mathrm{H} 2$ and $\mathrm{H} 3$, the assurance we 
International Journal of Business and Management Review

Vol.8, No.5, pp.68-99, August 2020

Published by ECRTD-UK

Print ISSN: 2052-6393(Print), Online ISSN: 2052-6407(Online)

have in the two assertions is slightly different $97,1 \%$ for $\mathrm{H} 2$ and $95,1 \%$ for $\mathrm{H} 2$, so not all statistically significant effects should be treated the same way. For H1, it was found that there is no significant relationship between the credit policy and the financial performance, as in establishing the relationship the asssurance given as per our regression model is $51,5 \%$.

\section{SUMMARY, CONCLUSION AND RECOMMENDATIONS}

\section{Summary}

\section{Credit Management and Performance of Commercial Banks}

The study found that that there is a correlation between the observed and predicted values of financial performance. Table 6 shows R-square representing the proportion of the variability in one series that can be explained by the variability of one or more series in a regression model; the regression model for the 6 years studied helped us explain almost half of variations in the financial performance based on credit management components.

The findings are in line with Oludhe (2011), who, in a similar study conducted in Kenya, he argues that credit risk management is related to financial performance as they influence earnings of banks. The study corroborates the findings of Okoth et al. (2013) indicating that there is a relationship between credit management and bank performance. It was established that poor asset quality or high non-performing loans to total asset are related to poor bank performance.

\section{Credit Management Components and Banks Performance}

Table 2 shows the correlation matrix of the credit management indicators to financial performance. From table 2, capital adequacy ratio was negatively related to performance in a significant proportion; this is in line with the conventional argument that higher capital ratios encourage banks to invest in safer assets, such as lower-risk loans or securities, which may affect bank performance (Okoth et al. 2013). Credit risk Control (NPL/TL) had a weak relationship between asset quality and financial performance of commercial banks in Uganda, this is in accordance with a study conducted in Kenya by Jackson (2011). Credit policy (LR) had also a weak relationship with financial performance.

The objective of the study was to establish the effects of credit management on the financial performance of Banks in Uganda. This was a descriptive and crosssectional study. It adopted a universal sampling technique were all the commercial banks licensed and operational in Uganda from 2012 was selected (24 banks).

The study used secondary data obtained from the audited financial statements of Banks in Uganda for the years 2012-2017. The variables of interest i.e. Credit Policy (LR), capital adequacy (CAR) and credit risk control were entered into statistical package for social sciences model and analyzed to examine their relationship and hence achieve the research objective.

The coefficients were put into a regression model to determine the relationship between independent and dependent variables in attaining the desired results on the 
study of interest. It is evident from our statistics that the coefficients of credit management are negative meaning that there is a negative relationship between credit management indicators and the performance. The findings reveal that all indicators used of the credit management explain a mere $41 \%$ of variation of the financial performances of banks in Uganda. This suggests that other factors apart from the credit policy, capital adequacy and credit risk control affect the financial performance of Banks in Uganda.

\section{Conclusions}

This study examined the relationship between credit management and bank performance in Uganda. Findings from our determination test indicate that about $40 \%$ of the variability in banks' performance (measured as ROE) can be explained by the attributes of the credit management.

The objective was to establish the effects of credit management on the financial performance of Banks in Uganda. The results indicate that there is a relationship between credit management variables and financial performance under the study but the effect is not too significant.

Empirical evidence from the study indicates that there is a negative relationship between asset quality and performance of commercial banks, to be specific, it was found that a unit decrease in the ratio of nonperforming loans to total loans will lead to an increase in financial performance by 1,005 . It also shows that a unit decrease in lending ratio will lead to an increase in financial performance by 0,031 , a unit decrease in capital adequacy ratio will lead to an increase in financial performance by 0.555 .

In addition, based on the hypotheses tested, findings from the study further provided evidence to support the arguments that ratio of non-performing loans and bad debt do have a significant negative effect on the performance of banks in Uganda. This outcome corroborates the suggestion that the higher the bad debts written off from the profit of the bank, the lower the ROE. The study concludes that banks management should establish sound credit management based on a moderate credit policy, because, however small, it was established in the study that the more the appetite to lend is, the more likely the bank will lose its efficiency in controlling loans, moreover they should comply with credits standards which encourage the banks to invest in safer assets, such as lower-risk loans or government securities, which may affect bank performance but strengthen their liquidity position and avoid difficulties like the one Crane Bank Uganda and NBC Uganda went through during the last past years.

\section{Recommendations}

I recommend to commercial banks in Uganda should use a moderate credit policy as a stringent credit will undermine the financial performance. Moreover, commercial banks should seek to adequately control their credit risk by keeping lower their ratio of nonperforming loans which is the major determinant of commercial banks' financial performance as shown in the study. They should finally endeavor to holding adequate capital for the sake of liquidity and going concern even if it undermines to some extent their capital to maximize financial performance. To the BOU, it's 
suggested to require banks in Uganda to use credit metrics model in controlling its risks. Moreover, the central bank should enforce its supervision and make sure all regulatory rules it has established are followed by commercial banks in Uganda

In addition, I recommend that commercial banks should organize effectively its credit risk control department as the asset quality depends heavily on how well credit risks are controlled in a banking institution. Banks in their quest to a higher financial performance should have to also concentrate on other factors affecting its operations.

The Bank of Uganda should keep providing supervisory activities to the entire industry. They should keep striving to have banks in Uganda with strong capital and liquidity buffers to provide the financial sector with a high degree of resilience to shocks such as losses on their loan portfolios.

\section{Limitations to the Study}

This study confined to the use of secondary data which raises reliability issues of the data used. Relying on the secondary data means that any error in the source will also be reflected in the research, that is, errors and assumptions not disclosed in the source documents will also reoccur in the research.

A salient limitation of this paper is the period for which the data is sampled. The sample horizon for this research is short compared to other related studies in the literature. To address this limitation, future research can increase the sample size and also examine the effect of other credit management variables on the financial performance of banks.

Moreover, no moderation or mediation effects were measured in studying the relationship between credit management indicators with the performance of commercial banks in Uganda; moderators or mediators should be included in future studies to come up with a model that can significantly explain the performance of commercial banks.

\section{Suggestions for Further Research}

There is further research that need to be done on this research to find out how the credit management is organized in the organizations. This will help to explain in a comprehensive manner if the financial performance is affected with the implementation of an adequate credit management policy in the organizations.

There is also a large percentage of other factors (positive or negative) that affect financial performance of banks which should be put into consideration since this research show that credit management does not have a significant impact on financial performance. Therefore, the other factors should be researched on; for instance, research should be done on the relationship between credit management and nonperforming loans on Banks in Uganda and on the reasons for loan default in Banks from a client' perspective.

Researchers should also study the moderating effects of variables like the inflation, the central bank rates, the GDP growth rate in the relationship between the credit management and performance of commercial banks in Uganda. Moreover, a more 
International Journal of Business and Management Review

Vol.8, No.5, pp.68-99, August 2020

Published by ECRTD-UK

Print ISSN: 2052-6393(Print), Online ISSN: 2052-6407(Online)

comprehensive cross-countries study should be undertaken encompassing all financial sectors in East Africa or Sub-Sahara Africa.

\section{REFERENCES}

Abedi, S. (2000). Highway to Success. Credit management Journal , 40-55.

Adeusi (2013). Risk Management and Financial Performance Of Banks In Nigeria . IOSR Journal of Business and Management (IOSR-JBM) ISSN: 2319-7668. Volume 14, Issue 6 , 52-55.

Alin Marius ANDRIEŞ \& Alexandru Ioan Cuza. (2009). Theories regarding financial intermediation and financial intermediaries. The annal of the "Ştefan cel Mare" University ofSuceava, 254-261.

Alvi, M. (2016). Manual for selecting sampling techniques in research. Karachi: Iqra University.

Angelo, Z. \& Paola, D. (2006). Bad Loans and Efficiency in Italian Banks. Verona: Dipartimento di Scienze Economiche - Università di Verona .

Antoine, N. (2015). Effect of loan management on the financial performance of commercial bank: the case of bank of Kigali (B.K). East African Journal of Science and Technology, 46-59.

Ara, H., Bakaeva, M. \& Sun, J. (2009). Credit Risk Management and Profitability in Commercial Banks in Sweden. Gothenburg : University of Gothenburg.

Arora, S. (2013). Credit Risk Analysis in Indian Commercial Banks : An Empirical Investigation. Asia-Pacific Finance and Accounting Review ISSN 2278-1838: Volume 1, No. 2, 25-33.

Ayadi, Rym et al.. (2015). Does Basel Compliance Matter for Bank Performance? IMF working paper 15/100. IMF.

Bagyenda, J. (2012, Septembre 22). Bank of Uganda executive director in charge of supervision and regulation. (U. R. Network, Intervieweur)

Bank for International Settlements . (2001). The New Basel Capital Accord.

Bank of International Settlement. (2008, July 17). Credit management. Retrieved from Bank of International Settlement website : www.bis.orgpublbcbsc125.pdf

Bank of Uganda . (2016). Annual Supervision Report. Kampala : Bank of Uganda .

Bart Baesens \& Tony Van Gestel. (2009). Credit Risk Management, Basic Concepts : financial risk components, rating analysis, models, economic and regulatory capital. New York: Oxford University Press.

Berger, A. \& DeYoung, R. . (1997). Problem Loans and Cost Effi ciency in Commercial Banks. Journal of Banking and Finance, Vol. 21, 849-870.

Bert Scholtens \& Dick van Wensveen. (2003). The theory of financial intermediation : An essay on what it does explain. Vienna : SUERF.

BOA Uganda. (2014). Annual reports . Kampala: BOA.

Boyd, A. (2012). How the industry has changed since deregulation. Personal Investment. International Journal of Arts and Commerce Vol $1 N^{\circ} 5,9-15$.

Bryman \& Bell. (2007). Ethical considerations in research.

Business Dictionary . (2017, October 12). What is credit policy . Retrieved from http://blog.e2banytime.com/what-is-a-credit-collections-policy-how-todevelop-one-that-drives-results/ 
Chinonye, O. \& Kelikume, I. \& Umoren, A. (2010). Effect of capital adequacy on banks' performance. Journal of Economics and finance, 1-17.

Çomakoğlu, A. (2017). Credit risk modelling and quantification . Boğaziçi University .

Eric, F. (2012). Assessing organizational performance in real time. Journal of Management systems, 25-45.

Fluid Surveys University. (2017, November 11). Determining the sample size. Retrieved from Fluid Surveys : fluidsurveys.com/university/calculating-rightsurvey-sample-size/

Fofack, H. (2005). Nonperforming loans in Sub-Sahara Africa: Causal analysis and macroeconomic implication. World Bank Policy Research Paper 3769 Vol. 21.

Furletti, M. (2002). An Overview and History of Credit Reporting. Philadelphia: Ten Independant Mall.

Gaskin, J. (2018, June 27). Structural Equation Techniques (Statistics). Retrieved from Statistics Wikipedia : statwiki.kolobkreations.com

Gatuhu, R. N. (2013). The effect of credit management of the financial performance of microfinance Institution in Kenya. Nairobi .

Gerlach, S. P. (2003). Macroeconomic conditions and banking performance in Hong Kong SAR: a panel data study. Hong Kong: Journal of Econometrics .

Ghazouani, I. (2016). Explanatory Factors of Credit Risk: Empirical Evidence from Tunisian Banks. International Journal of Economics, Finance and Management ISSN 2307-2466, 21-29.

Gordon G. \& Andrew W. (2003). Financial intermediation. Handbook of the Economics of Finance, 437-531.

Gurley, J. \& Shaw, E. (1960). Money in a theory of finance. Brookings .

Hayati, A. \& Mohamed, A. (2007). Mutli-country study of banks credit risk determinants. The International Journal of Banking and Finance, Vol. 5.(Number 1): , 135-152.

Higgins, J. (2005). The Radical Statistician .

Hildreth, R. (2001). History of Banks: a Demonstration of the Advantages and Necessity of Free Competition In the Business of Banking. Ontario: Batoche Books Limited.

Investopedia. (2017, September 20). Basel Accord. Retrieved from Investopedia: www.investopedia.com

Investopedia.com. (2017, October 12). Basel Accord. Retrieved from Investopedia.com: http://www.investopedia.com/terms/b/basel_accord.asp

Investopedia.com. (2018, June 27). Multicollinearity . Retrieved from Investopedia : https://www.investopedia.com/terms/m/multicollinearity.asp

Jamil, J. \& Abdullah A. (2014). Impact of external and internal factors on commercial bank profitability in Jordan. International Journal of Business and Management, 22-30.

JP Morgan \& Bank of America, Bank of Montreal, Swiss Credit Union. (2017, October 16). Credit Metrics Intro. Retrieved from RPI.EDU: http://homepages.rpi.edu/ guptaa/MGMT4370.09/Data/CreditMetricsIntro.pdf

Kaboyo, S. (2016, October 26). Managing partner, Alpha Capital Partners. (D. Monimtor, Intervieweur) 
International Journal of Business and Management Review

Vol.8, No.5, pp.68-99, August 2020

Published by ECRTD-UK

Print ISSN: 2052-6393(Print), Online ISSN: 2052-6407(Online)

Kabudula, C. (2015). Analysis of the credit risk management efficiency on financial performance in Malawi's commercial banking sector. Lilongwe: Blantyre International University.

Kakuru, J. (2003). The Management of loan portfolios and the performance of indigenous: A case study of Uganda Commercial Bank and Centenary. Kampala: Makerere Business School.

Kasekende, L. (2012, September 28). Deputy Governor, Bank of Uganda. (U. R. Network, Intervieweur)

Kristianti, R. \&. (2016). Factors Affecting Bank Performance: Cases of Top 10 Biggest Government and Private Banks in Indonesia in 2004 - 2013 . Review of integrative business \& economics, 371-378.

Lall, P. (2015). Managing Credit Risk in Small and Large U.S. Banks: Indicators from the 2007-2013 Financial Crises . International Journal of Economics, Finance and Management VOL. 4, NO. 4, 154-165.

Lebans, M. \& Euske, K. (2006). A conceptual and operational delineation of performance: Business Performance Measurement (Banks). Cambridge University Press.

Mboka, T. (2013). Effects of macro-economic variables on nonperforming loans of commercial banks in Kenya. Nairobi: (Unpublished MBA Dissertation), University of Nairobi, School of Business.

Mburu, I. (2014). The effect of intererst rate on financial performance of commercial banks in Kenya. Nairobi: (Unpublished MBA thesis) University of Nairobi, School of business.

Mike, A.-G. (2016). The Bankruptcy of Lehman Brothers: Causes, Effects and Lessons Learnt (ISSN: 2371-2112). Journal of insurance and financial management, 132-149.

Mohammed, U. \& Maijama, D. \& Adamu, M. (2014). Conceptual exposition of the effect of inflation on bank performance. Journal of World Economic Research , 55-59.

Mohd et al. (2010). Bank efficiency and non-performing loans : Evidence from Malaysia and Singapore. Prague : Prague Economic Paper.

Mugume, A. (2007). Market Structure and Performance in Uganda's Banking Industry. Kampala: School of Economics and Management, MUK.

Mulema, S. (2011). Credit policy and loan portfolio performance in microfinance institutions, case study of uganda finance trust central branch, Kampala. Kampala: Makerere University.

Myers and Brealey. (2003). Bank Risk Management Theory. New York: McGrawHill.

N. Cetorelli, B. Mandel \& L. Mollineaux . (2012). The evolution of banks and financial intermediation: Framing the analysis. Economic Policy Review , 1 12.

Nabila, Z. and Younes B. . (2011). The factors influencing bank credit risk: The case of Tunisia . Journal of Accounting and Taxation, 70-78.

Negera, W. (2012). Determinants of Non Performing Loans, Case of Ethiopians Banks. Pretoria: School of Business Leadership, UNISA.

Nelson, M. \& Victor, M. (2009). Commercial banking crises in Kenya: Causes and remedies . Global Journal of Finance and Banking Issues , 23-43. 
International Journal of Business and Management Review

Vol.8, No.5, pp.68-99, August 2020

Published by ECRTD-UK

Print ISSN: 2052-6393(Print), Online ISSN: 2052-6407(Online)

Northwest Farm Credit Services. (2008). How lending decisions are made. Spakane: NWFCS Business tool.

Nsambu, K. (2014). Factors Affecting Performance of Commercial Banks in Uganda A Case for Domestic Commercial Banks. 25th International Business Research Conference (pp. 1-19). Cape Town: South Africa, ISBN: 978-1922069-42-9 .

Ntabazi, S. (2013). Causes of non-performing in commercial banks: A case study of $R U K W A$ and $C R D B$ Bank. Dar Es Salaam: Mzumbe University.

Nyawera, N. (2013). The effect of credit policy on the financial performance of Deposit Taking Microfinance Institution in Kenya. Nairobi.

Nzioka, P. (2013). The relationship between firm size and financial performance of commercial banks in Kenya. Nairobi: University of Nairobi.

Ogilo, F. (2012). The Impact of Credit Risk Management on Financial Performance of Commercial Banks in Kenya . Africa Management Review , 22-37.

Olawale, S. (2015). The effect of credit risk on the performance of commercial banks in Nigeria . Journal of Business and Economics, 60-79.

Oldfield, G. \& Santomero, A. (1997, July 20). The Place of Risk Management in Financial Institutions. Retrieved from Wharton official Website: fic wharton.upenn.edu/fic/papers/95/9505.pdf

Oludhe, K. (2011). The impact of credit risk management on financial performance of commercial banks in Kenya. Kenya : University of Nairobi.

Owaah, K.. (2017, November 28). Why Kenyan Banks fails. Retrieved from Owaah: http://owaahh.com/kenyan-banks-fail/

Pamela, N. (2012). Credit terms, access to finance and financial performance of SMES in Kampala. Kampala : MUK.

Pandey, I. (2003). Financial Management. Vikas publishing House PVT Ltd.

Parkin, M. \& Blade. (2015). Microeconomics: Canada in the global environment (9th Edition). Ottawa: Pearson Canada.

Pasiouras \& Kosmidou, K. (2007). Factors influencing the profitability of domestic and foreign commercial banks in the European Union,. International Business and Finance, 222-237.

Pastor, J. (1999). Credit Risk and Efficiency in the European Banking systems : a Three-stage analysis. Valencia : Fundacion Caja Madrid .

Paul, M. (2002). The 1998-99 banking crisis in Uganda: What was the role of the new capital requirements? Journal of Financial Regulation and Compliance, 55-85.

PWC. (2017, October 12). Credit risk management. Retrieved from PWC: https://www.pwc.com/la/en/risk-assurance/credit-risk-management.html

Rabbi, M. M. (2010). History of Banks from the millenium age to early forms of banking. New York: New York Works Press.

Ravi, P. (2012). The impact of credit risk management on financial performance of commercial banks in Nepal . International Journal of Arts and Commerce , 915.

Reicheld, Z. \& Sasser,N. (2010). Enhancing customer retention through relationship . Journal of Marketing , 50-89.

SageWorks. (2014). Quantifying the 5 Cs: Credit analysis and ratios that matters. Sage Works. Retrieved from www.sageworksanalyst.com 
Sayedi, S. (2013). Bank specific, industrial specific and macroeconomic determinants of banks profitability in Nigeria. Journal of Finance , 65-80.

Sharma, P. (2012). The impact of credit risk management on financial performance of commercial banks in Nepal. International Journal of Arts and Commerce Vol. 1 No. 5 , 9-15.

Shehzad Khan, Faizan Malik \& Faisal Khan. (2014). Interest rates and it effects on bank's profitability. Kualalumpur : Research Gate.

Suleiman, M. \& Sharif, M. . (2013). Methods of Evaluating Credit Risk used by Commercial Banks in Palestine. International Research Journal of Finance and Economics ISSN 1450-2887, 147-159.

Tucker, M. (2004). Financial performance of microfinance institutions: a comparison to performance of regional commercial banks by geographic regions. Journal of Microfinance/ESR Review, pp. 41-54.

Turyahebwa, A. (2013). Financial Performance in the Selected Microfinance Institutions. Kampala: (unpublished masterees thesis) Kampala International University, West Campus .

Uganda Rapdio Network. (2018, March 19). BoU: National Bank of Commerce Was in Financial Mess. Retrieved from Uganda radio network : https://ugandaradionetwork.com/story/bou-national-bank-of-commerce-wasin-financial-mess

Uwalomwa, Uwuigbe \& al. (2015). Credit Management and Bank Performance of Listed Banks in Nigeria . Journal of Economics and Sustainable Development (ISSN 2222-2855), 27-32.

V. Okoth \& G. Beghanu. (2013). Determinants of Financial performance of commercial Banks in Kenya. International Journal of Economics and Financial Issues, 237-252.

Wachira, D. (2015). The effect of credit policy on the financial performance of Banks and SACCOS in Kenya. Nairobi: (Unpublished MBA dissertation) University of Nairobi, School of Business.

Waithaka, N. (2013). The effect of of Basel II requirement on Kenya Commercial Banks" lending. Nairobi: Unobi.

Wikipedia. (2017, October 12). Banking in Uganda. Retrieved from Wikipedia: https://en.wikipedia.org/wiki/Banking_in_Uganda

Wikipédia. (2017, October 17). Basel II. Retrieved from Wikipédia: https://en.wikipedia.org/wiki/Basel_II

Wikipedia. (2017, September 5). Banking in Uganda. Retrieved from Wikipedia : en.wikipedia.org/wiki/Banking_in_Uganda

Williams, D. (2003). Measuring government in the early twentieth century,. South American Journal of Public Administration review, pp. 550-580 